\title{
Does Typha spp. Contribute to Wetland Waterloss and Health Risk: A Case Study of Hadejia Nguru Wetlands (HNW) System NE Nigeria
}

\author{
Gabriel Salako ${ }^{1,2}{ }^{*}$, Henry Sawyerr ${ }^{1}$, Oluwasogo Olalubi ${ }^{3}$ \\ ${ }^{1}$ Department of Environmental Management and Toxicology, Kwara State University, Malete, Nigeria \\ ${ }^{2}$ Department of Forest Ecosystem and Society, Oregon State University, Corvallis, USA \\ ${ }^{3}$ Department of Public Health, Kwara State University, Malete, Nigeria \\ Email: "gabsalako@yahoo.co.uk, "gabriel.salako@kwasu.edu.ng
}

Received 12 January 2016; accepted 19 February 2016; published 22 February 2016

Copyright (C) 2016 by authors and Scientific Research Publishing Inc.

This work is licensed under the Creative Commons Attribution International License (CC BY).

http://creativecommons.org/licenses/by/4.0/

(c) (i) Open Access

\begin{abstract}
The role of Typha spp. on water loss and public health has been uncertained and relatively poorly reported in Hadejia Nguru wetlands. This study investigated the extent to which Typha spp. contributed to evapotranspirative water loss and the level at which it provides suitable habitat for mosquito breeding. A comparative analysis between Typha swamp and open water was made to determine the evapotranspiration water loss and mosquito larva load accounted for by Typha swamp in the wetland. Maximum and minimum temperatures were measured and recorded daily for the months of January, March and June in 2013. Blaney-Criddle equation was used to estimate the evapotranspiration from Typha swamp (Site A) while piche evaporimeter was used to measure direct evaporation from the adjacent open water (Site B). Water samples were collected in Sites $A$ and $B$ using $100 \mathrm{ml}$ beaker at random and the number of mosquito larvae in the sample was counted. $T$ test was used to evaluate differences in water loss and larva load between open water and Typha swamp in the wetland. The findings revealed that there was no significant difference in water loss at $p<0.05$ between Typha swamp and open water in the wetland. However, the Typha swamp was found to harbor more mosquito larvae than the open water at $p<0.05$ which was considered a public health risk.
\end{abstract}

\section{Keywords}

Evapotranspiration, Typha Swamp, Wetlands, Mosquito Larva, Water Loss

\footnotetext{
${ }^{*}$ Corresponding author.
}

How to cite this paper: Salako, G., Sawyerr, H. and Olalubi, O. (2016) Does Typha spp. Contribute to Wetland Waterloss and Health Risk: A Case Study of Hadejia Nguru Wetlands (HNW) System NE Nigeria. Open Journal of Ecology, 6, $151-158$. 


\section{Introduction}

Typha grass is an emergent monocotyledon which produces erect, approximately linear leaves from extensive anchoring systems of rhizomes and roots. It is one of the prominent emergent macrophytes in wetlands or flooded areas and perhaps among the notorious plants causing economic hardship in the tropics [1] especially in an otherwise productive wetland [2]. Typha grass has been identified nearly 40 years ago by the locals in the Marma channel-Nguru lake complex located on longitude 10.4086E and latitude 12.3565N in Yobe state north east Nigeria [3]. The spots were popularly known as Kachala ponds. The size of the spots was about $30 \mathrm{~m}^{2}$ in the early 70s; however by 2003 the continuous and permanent inundation of the lake has aided the rapid growth of Typha to maturity [4]. Two small patches of the Typha grass were found to have been growing near Badin pond in Nguru Lake. Bdliya and Mohammed, [5] reported that the most outstanding impact of the threats on the Wetland is the creation of a conducive condition for Typha invasion, which now occupies over $200 \mathrm{~km}^{2}$ of farmlands and fishing grounds. It has also contributed to the blockage of several channels.

The effect of Typha or any other aquatic plant on evapotranspirative water loss has been mixed [6], while some findings showed that there are evidences of considerable quantities of water loss from wetland system due to invasion of aquatic plant [7]-[9], and other studies were in contrast [10] [11]. It was evidenced that certain parameters influence the result and findings on evapotranspirative water loss from aquatic plants: These are 1) type of plant under investigation, 2) the density or coverage [12], 3) the period of investigation [10] and 4) the choice of method used: direct measurement or indirect measurement [9].

Loss of water in the wetland could present a great danger not only to the survival of aquatic organisms such as fish but also to the flood recession rice farmers which depend on its moisture in dry season for operation.

Despite a number of studies that have shown that certain vectors have preferences for certain vegetation, the connection between the presence of certain disease in the human community and the aquatic vegetation in nearby water bodies is not always clear [6]. Probably the most serious adverse effects of aquatic weeds on human welfare in the long term is the extent to which they harbour agents which are vectors for disease in man and animals, principal of which are malaria and schistosomiasis. Parasites which cause some of the most devastating human diseases are usually animals of wetlands [13]. Malaria is perhaps the most prevalent of these diseases. Water among aquatic plants is ideal for mosquito breeding as long as it is not completely deoxygenated [13]. This study therefore investigated the role of Typha spp. in evapotranspirative water loss and also assessed its health risks by assessing the level at which it provides suitable habitat for mosquito breeding in the wetlands (Plate 1).

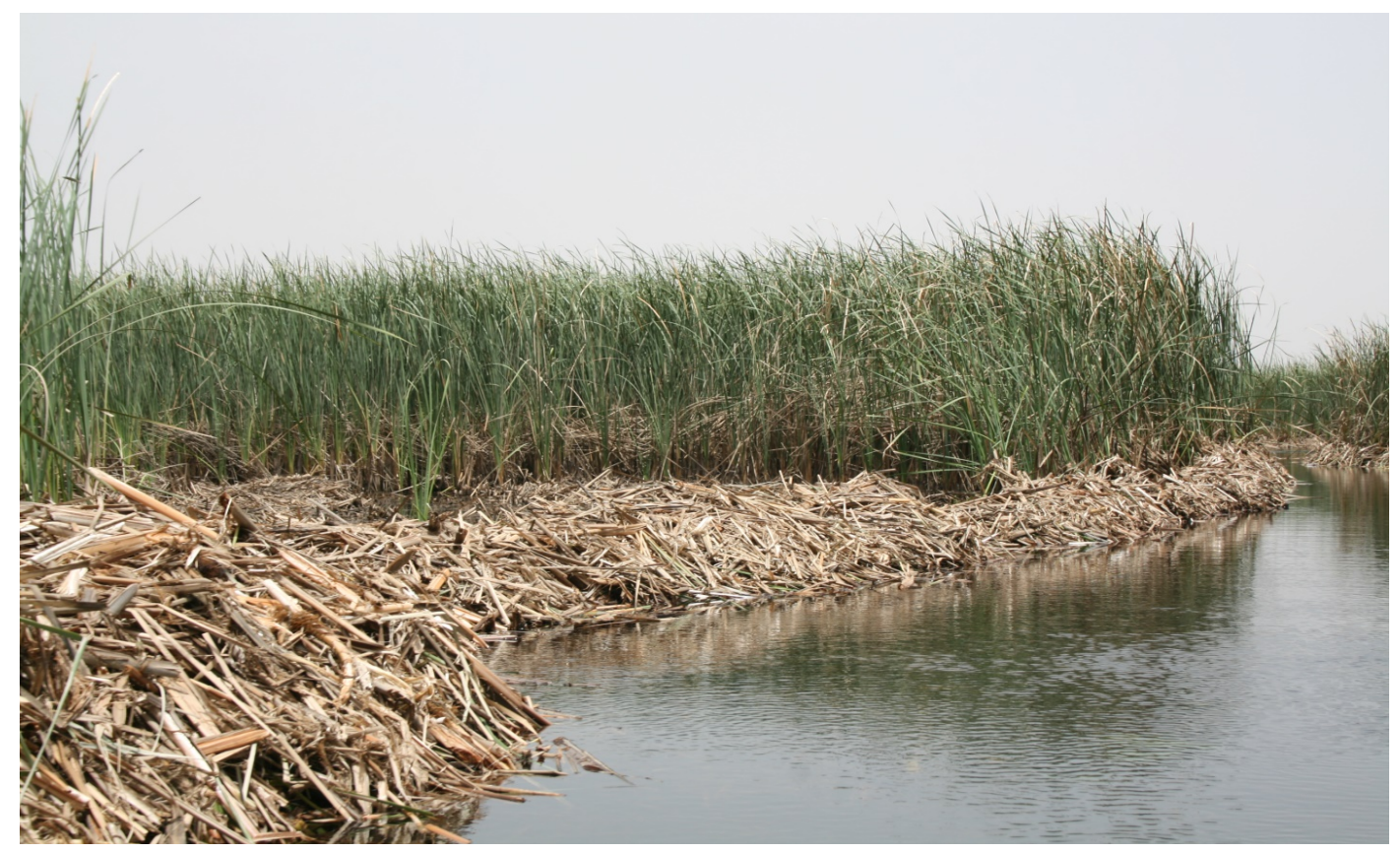

Plate 1. A colony of Typha spp. intersperse with open water at Bambori near Nguru. Source: Hadejia Nguru wetlands conservation project Nguru station 2013. 


\section{Materials and Methods}

\subsection{Study Area}

The Hadejia-Nguru Wetlands (HNW) is located between latitude $12^{0} 15^{1}$ and $13^{0} \mathrm{~N}$ and longitude $10^{0} 00^{1}$ and $11^{0} 12^{1} \mathrm{E}$ in Nigeria and occupies an area of $3500 \mathrm{~km}^{2}$, bounded by routes linking Hadejia, Katagum, Nguru and Gashua town. The Hadejia-Nguru Wetlands (HNW) run through the semi-arid environment of north western and north eastern parts of Nigeria, cutting across Kano, Bauchi, Jigawa, and Yobe States of Nigeria and supporting over 7 million population including migrants from Niger Republic [5]. The study area was limited to the upper section of the wetland between Jigawa and Yobe states (Figure 1) covering 5 selected settlements within the wetlands: Wachakal, Zuggo, Marma, Adiyani and Bambori/Nguru.

\subsection{Field Experimental Procedure}

Data collected through field experiment were evapotranspiration water loss, mosquito larva load (number per $100 \mathrm{ml}$ ), the larvae collected were heat killed (tepid, not boiling) preserved in 80\% ethyl alcohol and examined under a microscope of 60× magnification [14]. Other field work include determination of the size of fish ground and farm land under Typha infestation (ha). Questionnaire was designed to capture data on exposure to mosquito bite and malaria reported cases. Field investigation was conducted to determine and compare rate of water loss in Wetland due to Typha infestation as against open water. Wachakal (Figure 1) was selected as our temporary weather station and site for evapotranspiration assessments for the period of investigation. In the selected village, (1) Typha infested site of $1 \mathrm{~m}^{2}$ was laid at random called Site A, also, 1 site of open water at $1 \mathrm{~m}^{2}$ was equally laid called site B [7] [15]. Maximum and minimum thermometer were installed at the Typha Swamp in Site A to take the average daily temperature for months of January, March and June 2013. A Piche evaporimeter was installed at the bank of the open water in Site B to measure daily evaporation for the same period [15]. From the record obtained in Site A, an average monthly temperature was extracted and Blaney-Criddle method was applied to determine the potential evapotranspirative water loss [16]-[18] due to Typha invasion. Also the record obtained in Site B was used to determine average monthly evaporation for the period under investigation.

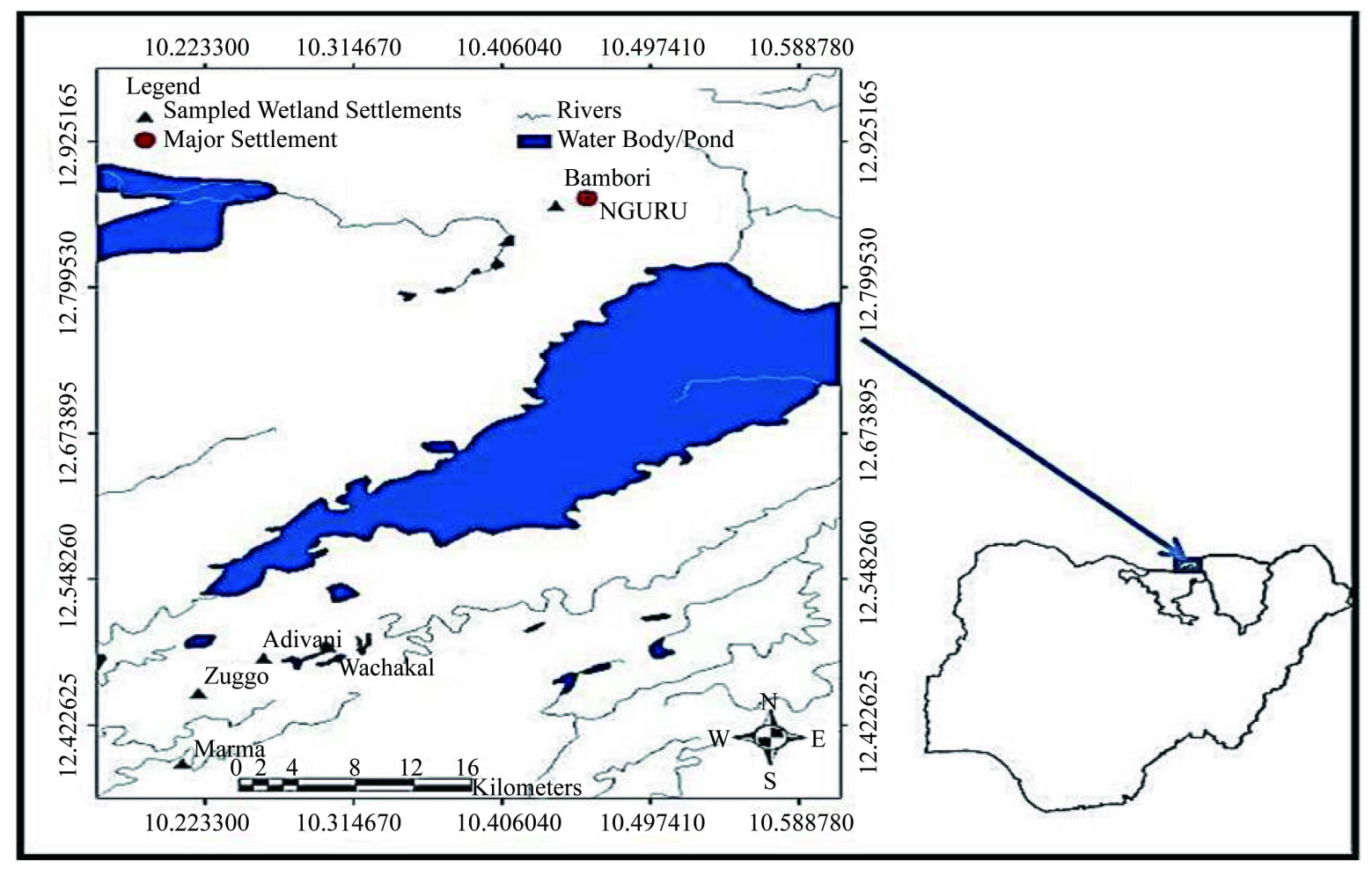

Figure 1. Map of Hadejia Nguru Wetlands (HNW) showing the selected settlements in the study area (inset host states in Nigeria). 
To determine the larva load due to Typha infestation, Bambori, a settlement of three kilometers west of Nguru was selected as our experimental site for mosquito larva load because of its closeness to Nguru, the major urban centre in the wetland and its dense Typha swamp. Ten samples of water were randomly taken from both Typha swamp and open water (Table 1). At each site A and B, average of ten water sample were collected using 100 $\mathrm{ml}$ beaker at random and the number of mosquito larva in the sample collected for each site were counted. To determine the proportion of farmland and fishing ground infested by Typha, we took the simple linear measurement of the farm size and fishing ground area of each respondent using Linen measuring tape.

Farmers and fishermen $(n=200)$ were visited on their farmland and fishing ground where questionnaires were administered (Table 2) the focus is the wetland farmers and fishermen in each of the five sampled villages. Where the respondents were not literate, the researcher and his assistant interpreted the questionnaires and recorded their responses. Issues addressed in the questionnaire were exposure to mosquito bite, malaria infestation reported cases and general perception of wetlands. Administration was done between 08:00 hrs-12:00 hrs local time, being the hours the respondents were most likely to be on their respective farmland and fishing site between June-July 2013. The main descriptive statistics (totals, percentage, mean) were used to summarize data.

Student $t$-test was performed in Microsoft Excel software (2013) to test the two postulated hypotheses: 1) Ho-there is no significant difference in water loss between Typha infested swamp and open water wetland. 2) Ho-Typha swamp does not harbor mosquito larva more than the open water area of wetlands. Blamey-Criddle method was adopted [16] [18] in determining the potential evapotranspiration/consumptive use (CU). Because of its simplicity and adaptability [18].

Equation (1) Blaney-Criddle equation

$$
C U=\mathrm{Kf}: \mathrm{f}=\frac{(1.8 \mathrm{Tm}+32) \mathrm{P}}{39.37}
$$

Table 1. Mosquito larva load in Typha swamp and open water (number/100ml).

\begin{tabular}{ccc}
\hline Sample point & Mosquito load in Typha swamp $\left(X_{1}\right)$ & Mosquito load in open water $\left(X_{2}\right)$ \\
\hline 1 & 07 & 03 \\
2 & 06 & 02 \\
3 & 16 & 04 \\
4 & 14 & 04 \\
5 & 10 & 02 \\
6 & 21 & 01 \\
7 & 01 & 00 \\
8 & 02 & 01 \\
9 & 04 & 03 \\
10 & 11 & 02 \\
Total & 92 & 22
\end{tabular}

Source: Field survey 2013.

Table 2. Allocation of questionnaires in sampled villages.

\begin{tabular}{|c|c|c|c|c|}
\hline Settlements & Population & Total allocated & Farmers & Fishermen \\
\hline Wachakal N & 3765 & 44 & 22 & 22 \\
\hline Zuggo & 2507 & 29 & 14 & 15 \\
\hline Marma & 6703 & 78 & 39 & 39 \\
\hline Adiyani & 3208 & 37 & 18 & 19 \\
\hline Bambori/Nguru & 1041 & 12 & 04 & 08 \\
\hline Total & 17224 & 200 & 97 & 103 \\
\hline
\end{tabular}

Source: Field survey, 2013. 
where $\mathrm{f}=$ Monthly consumptive factor;

$\mathrm{Tm}=$ Mean monthly temperature;

$\mathrm{K}=$ Average consumptive use or coefficient factor of the plant/crop; 0.75 for Typha;

$\mathrm{P}=$ Monthly $\%$ of annual day time hours;

Computing \% annual day times hours,

where hdi =day time hours for dayi;

$$
\text { hdi = (hsi) (hdoi)/90; }
$$

hsi =sunrise or sunset hour angle (degree);

hdoi =day time hours at zero declination for dayi;

$\mathrm{P}=$ (hdi/ha); ha $=\Sigma$ hdi;

$\mathrm{Ha}=$ total day time hours per year.

Equation (11) Student $t$-test

$$
t=\frac{X_{1}-X_{2}}{s_{X_{1} X_{2}} \times \sqrt{\frac{1}{n}}} .
$$

\section{Results and Discussion}

\subsection{Evapotranspiration and Evaporation Water Loss from Typha Swamp and Open Water}

Table 3 presents the corresponding results of open water and Typha swamp water loss in the three intervening periods. Data was subject to student $t$-test for possible differences, the result revealed that the calculated $t$ value of 0.408 is less than the critical $t$ value of 2.776 (Table 4 ) at $\mathrm{p}<0.05$. The Ho (1) was therefore accepted, implying that there is no significant difference in water loss between the two samples. The comparative analysis on evapotranspiration water loss does not show any significant difference between Typha swamp and open water. $\mathrm{T}$ and therefore it may not have been the reason for the reduction in water level in the wetlands. This, although contrast the findings of Wetzel [12] [19] and Goulden et al., [9] which supported that evidence of considerable

Table 3. Average monthly evapotranspiration and evaporation water loss from Typha swamp and open water.

\begin{tabular}{ccc}
\hline Months & ${ }^{*} \mathrm{X}_{1}(\mathrm{~mm})$ & ${ }^{*} \mathrm{X}_{2}(\mathrm{~mm})$ \\
\hline January & 338 & 328 \\
March & 480 & 499 \\
June & 361 & 246 \\
Total & 1179 & 1073 \\
\hline
\end{tabular}

*Average monthly values, $\mathrm{X}_{1}=$ Evapotranspiration water loss from Typha swamp, Blaney-Criddle equation (Equation (1)). $\mathrm{X}_{2}=$ Evaporation water loss of open water. Source: Field experiment, 2013.

Table 4. T test (Equation (2)) summary for water loss in Typha swamp and open water.

\begin{tabular}{ccc}
\hline & & $X_{1}(\mathrm{~mm})$ \\
Mean & 393 & 357.6667 \\
Variance & 5809 & 16662.33 \\
Observations & 3 & 3 \\
Pooled variance & 11235.67 & 0 \\
Hypothesized mean difference & 4 \\
Df & 0.408254 \\
$\mathrm{P}$ Stat $\leq t)$ one-tail & 0.351998 \\
$t$ Critical one-tail & 2.131847 \\
$\mathrm{P}(\mathrm{T} \leq t)$ two-tail & 0.703996 \\
$t$ critical two-tail & 2.776445 \\
\hline
\end{tabular}


quantities of water loss from wetland system was due to invasion of aquatic plant such as Typha. The Typha density in the experimental site was observed not to be high enough and could have been possible reason for insignificant difference [12]. However, other preliminary observation shows that the grass being a good "trapper" of sediment could have facilitated accumulation of sediment which perhaps lower the water depth and consequently reduce the water level.

\subsection{Typha Swamp and Mosquito Larva Load}

Two species of Mosquito were found in the wetland $87 \%$ was of Anopheles gambiae and $13 \%$ of Culex pipiens species. The result of statistical test revealed that the calculated $t$ value of 3.366 is greater than the critical $t$ value of 2.100 at 95\% significant level (Table 5). That suppose there is a significant difference between the two sampled means, the Ho (2) was rejected. It therefore suggest that Typha swamp harbour more mosquito larva than the open water. This supports the earlier findings of Moss [13], and Russell [20] that Malaria was perhaps the most prevalent disease among aquatic plants because it was ideal for mosquito breeding as long as the area was not completely deoxygenated. The possible explanation for this is that Typha grass provides a good habitat for the laying and hatching of mosquito eggs as it shelters it against high insolation and wind speed [13] [21].

This result was further affirmed by the mosquito bite sample survey conducted in the five selected villages (Table 6) where over $67 \%$ cases of mosquito bite were recorded.

\subsection{Methods of Typha Controls among the Locals}

Manual weeding was the commonest method being adopted by most respondents (90\%) to control Typha in the study area. Manual weeding involve cutting by using cutlass and sickle, a simple and less expensive implement. Although the majority of fishermen and farmers use manual weeding as control measure yet the success rate is much higher among farmers than fishermen. $7.5 \%$ of the respondents used machine to cut Typha grass prior to

Table 5. T test summary for Mosquito larva load for Typha swamp and open water.

\begin{tabular}{|c|c|c|}
\hline & Typha swamp & Open water \\
\hline Mean & 9.2 & 2.2 \\
\hline Variance & 41.51111 & 1.733333 \\
\hline Observations & 10 & 10 \\
\hline Pooled variance & 21.62222 & \\
\hline Hypothesized mean difference & 0 & \\
\hline Df & 18 & \\
\hline t Stat & 3.366145 & \\
\hline $\mathrm{P}(\mathrm{T} \leq \mathrm{t})$ one-tail & 0.00172 & \\
\hline t critical one-tail & 1.734064 & \\
\hline $\mathrm{P}(\mathrm{T} \leq \mathrm{t})$ two-tail & 0.00344 & \\
\hline t critical two-tail & 2.100922 & \\
\hline
\end{tabular}

Table 6. Reported cases of mosquito bite.

\begin{tabular}{cccc}
\hline Villages & Total case sampled & Mosquito bite reported cases & \% of mosquito bite to total case sampled \\
\hline Wachakal N & 44 & 27 & 18 \\
Zuggo & 29 & 56 & 62.06 \\
Marma & 78 & 26 & 71.79 \\
Adiyani & 37 & 08 & 70.27 \\
Bambori & 12 & 135 & 66.66 \\
Total & 200 & & 67.50 \\
\hline
\end{tabular}


farming operation. The use of biological control is null, while the use of chemical was observed among the few educated ones (5\%). Biological control is another option that can be taken into consideration in HNW as no cases was recorded to have used this method.

\section{Conclusion and Recommendations}

Typha swamp has become a health risk as findings had shown that it harbours more mosquito larvae than open water. It is therefore imperative that a rural health facility center within $1 \mathrm{~km}$ radius cycling distance of the study area is recommended to take care of the wetland dwellers most especially on prompt detection, early diagnosis and adequate treatment and management of malaria. However, the comparative analysis on evapotranspirative water loss does not show any significant difference between Typha swamp and open water and therefore it may not have been the reason for the reduction in water level in the wetlands. The control measure or coping strategy has only been limited to manual weeding which is energy sapping and time consuming. As it was observed, there was no tangible assistance being provided from government or donor agencies to help in fighting the menace pose by Typha invasion; however, introduction of mechanical control using environmentally adapted machine is highly recommended. Although use of chemical was recorded, this was used by fishermen for fish harvesting rather than the management of Typha. This practice should however, be discouraged through serious community based enlightenment campaign.

\section{References}

[1] Akobundu, O.I. (1987) Weed Science in the Tropics Principles and Practices. John Willey and Sons, New York, 45.

[2] Botkin, D.B. and Keller, A.E. (1998) Environmental Science Earth as Living Planet. John Willey and Sons Inc., New York.

[3] Bdliya, H.H. (1988) Guidelines for Wise Use of Hadejia-Nguru Wetlands Technical Reports. International Union of Conservation of Nature IUCN.

[4] Danjaji, M.M. (2007) Assessing the Environmental Impact Cattail Grass on Agricultural Practices along Marma Channel-Nguru Lake of Hadejia Nguru Wetlands. Unpublished Report College of Education Project, Umar Suleiman College of Education Gashua.

[5] Bdliya, H.H. and Mohammed, C. (2003) Threats to and Threats from Wetlands in the Management of the Komadugu Yobe Basin in Challenge to Sustainable River Basin Development in Nigeria. Nigeria Association of Hydrological Sciences (NAHS).

[6] Denny, P. (1985) The Ecology and Management of African Wetlands Vegetation. W. Sunk Publisher, Dordrecht. http://dx.doi.org/10.1007/978-94-009-5504-2

[7] Burian, K. (1971) Primary Production, Carbon Dioxide Exchange and Transpiration in Phragmites Communis on the Lake Neusiedler See Austria. Hydrobiologia, 2, 203-218.

[8] Timer, C.E. and Weldon, L.W. (1967) Evapotranspiration and Pollution of Water Hyacinth. Hyacinth Control Journal, 6, 34-37.

[9] Goulden, M.L., Litvak, M. and Miller, S.D. (2007) Factors That Control Typha Marsh Evapotranspiration. Aquatic Botany, 86, 97-106. www.elsevier.com/locate/aquabot http://dx.doi.org/10.1016/j.aquabot.2006.09.005

[10] Linacre, E.T., Hicks, B.B., Sanity, G.R. and Granze, G. (1970) The Evaporation from a Swamp. Agricultural Meteorology, 7, 375-386. http://dx.doi.org/10.1016/0002-1571(70)90033-6

[11] Rijks, D.A. (1969) Evaporation from a Papyrous Swamp. Quarterly Journal of the Royal Meteorological Society, 95, 653-649. http://dx.doi.org/10.1002/qj.49709540515

[12] Wetzel, R.G. (1999) Biodiversity and Shifting Energetic Stability within Fresh Water Ecosystem. Archiv für Hydrobiologie Special Issues Advances in Limnology, 54, 19-32.

[13] Moss, B. (1993) Ecology of Fresh Water: Man and Medium. Black Well Scientific Publication, Oxford. National Environmental Policy Act Clean Water Act Section 404. United States (US).

[14] Huang, Y.M. (2002) A Pictorial Key to the Mosquito Genera of the World, including Subgenera of Aedes and Ochlerotatus (Diptera: Culicidae). Insecta Koreana, 19, 1-130.

[15] Brezny, O., Mehta, I. and Sharma, R.K. (1973) Studies on Evapotranspiration of Some Aquatic Weeds. Weed Science, 21, 197-204.

[16] Blaney, H.F. and Criddle, W.D. (1962) Determining Consumptive Use and Irrigation Water Requirement. USDA 
Technical Bulletin No. 1275.

[17] Allen, R.G. and Pruitt, W.O. (1986) Rational Use of the FAO Blaney-Criddle Formula. Journal of Irrigation and Drainage Engineering, 112, 139-155. http://dx.doi.org/10.1061/(ASCE)0733-9437(1986)112:2(139)

[18] Fooladmand, H.Z. (2011) Evaluation of Blaney-Criddle Equation for Estimating Evapotranspiration in South of Ran. African Journal of Agricultural Research, 6, 3103-3109.

[19] Wetzel, R.G. (2001) Limnology: Lake and River Ecosystem. Academic Press, New York.

[20] Russel, R.C. (2006) Artificial Wetlands and Mosquito Control in Australia. In: Kay, B.H., Ed., Water Resources: Health, Environment and Development, E \& FN Spon Ltd., New York, 141-159.

[21] Kolinge, S.K. and Ray, C. (2006) Disease Ecology: Community Structure and Pathogen Dynamics. Oxford University Press, Oxford, 227 p. http://dx.doi.org/10.1093/acprof:oso/9780198567080.001.0001 